\title{
What Motivate Sudanese Students to Learn English as a Foreign
}

\section{Language?}

\author{
Elham Izeddin Yahia \\ St. John’s University, New York City, USA
}

\begin{abstract}
While there are several research studies that planned to discover what drives students' motivation to learn English as a foreign/second language, to our knowledge there have been no pragmatic studies in the field of EFL that examined Sudanese college-level students learning motivation. This study, therefore, intends to investigate Sudanese college-level students' motivation and its correlation to student's achievement. With strong emphasis on motivation, this study is, also examining the relationship between students' motivation and achievement when learning English as foreign language. The participants in this study were college-level students in Sudan. The data was collected from 60 college level students. This quantitative study employed both Pearson Correlation methods of analysis as well as ANOVA Regression analysis. The results of this study revealed that there is strong correlation between students’ motivation and students’ achievement.
\end{abstract}

Keywords: motivation, English as a foreign language, Sudanese students, college level, achievement

\section{Introduction}

Extreme demographic changes in classrooms in recent decades, as well as the impact of globalization on expectations regarding fluency in English (today's "lingua-franca”), have made it incumbent upon researchers to shed more light on the learning and teaching issues that impact English learners, in both the English as a foreign language (EFL) and English as a second language (ESL) contexts. In this regard, many studies have examined learners' motivation and its relationship to their academic achievement. These studies have focused on a number of factors, including intrinsic value, extrinsic value, values for achievement, self-efficacy, self-schema, prior knowledge, cultural background, and socio-economic status (Bandura \& Locke, 2003; Eccles \& Wigfield, 2002; Ruddell \& Unrau, 1997/2004; Wigfield \& Eccles, 2000). However, few EFL studies seem to have addressed the impact of motivation and gender on students' motivations; further, hardly any studies seem to have examined the conjoint effect of said issues. It is these issues that the present study seeks to address using a sample of college-level EFL students in the Republic of Sudan, which is a developing, predominately Arabic-speaking nation in northeast Africa.

There is wide agreement among researchers that motivation is a vital key to learning (Wigfield \& Eccles, 2000; Wigfield \& Guthrie, 1997). However, motivated individuals can exhibit a wide range of behaviors, feelings, and cognition that demonstrate their interest in completing particular tasks (Masgoret \& Gardner, 2003).

Dr. Elham Izeddin Yahia, Adjunct Professor, School of Education, St. John’s University. 
Researchers have therefore attempted to investigate the constructs and components that might make up and/or define motivation using various pathways of analysis. In particular, many studies have confirmed the relationship between motivation and achievement, as well as between motivation and student's self-efficacy (Alexander, 1997; Alharthy \& Was, 2010). The present study builds on this work, as well as on that of researchers who have investigated the correlation between English language learners' (ELLs) sense of self-efficacy and their motivation to learn English (Bandura \& Locke, 2003). In order to do so, this study seeks to investigate the impact of motivation on students' achievement using quantitative methods.

Researchers have studied the impact of different types of assessments on learners' self-efficacy and motivation (Huang, 2010). Other experimental studies examine the English Language Learners' (ELLs) motivational beliefs, values, and goals while reviewing recent research and focusing on the theories of developmental and educational psychology (Eccles \& Wigfield, 2002). Some studies believe it is favorable to examine the learners' motivation in relation to comprehension (Lincolin \& Rademacher, 2006; Ruddell \& Unrau, 1997/2004).

Other theories have focused on a numbers of motivational factors/constructs including intrinsic value, extrinsic value, values for achievement, self-efficacy, self-schema, prior knowledge, cultural background, and students' socio-economic status (Bandura \& Locke, 2003). Researchers have examined motivation from different perspectives, and several definitions of the construct have been given. In the context of foreign languages, Gardner (1985) described motivation as the mixture of efforts and desire to achieve ones goal combined with positive attitudes towards learning.

\section{Purpose and Significance of the Study}

This study sought to investigate the relationship between motivation, and achievement among students learning English as a foreign language in a developing country, namely Sudan. Quantitative data and methods were employed. It is hoped that discussion of the quantitative analyses will provide insights that will be helpful to educators in developing methodologies that successfully incorporate motivational tools, particularly for EFL students in developing country contexts. Furthermore, it is hoped that quantitative methods approach will serve as a model for similar studies in the future.

\section{Research Questions}

According to the MLEFL survey, what are the motivational factors for sophomore and seniors, male and female Sudanese college students to learn English as a foreign language?

Is there a significant difference between TOEFL scores of males and females, sophomores and seniors Sudanese college level students?

What is the relationship between motivation and achievement for college level Sudanese students?

\section{Literature Review}

Researchers explain motivation as people's choice of achieving task and how their motivation is influencing their choice, persistence, and performance (Wigfield \& Eccles, 2000). Motivating students in the EFL classroom is often a complex and difficult task that involves a multiplicity of psycho-sociological and linguistic factors 
(Dörnyei, 1998; 2010), but most English teachers will attest to the important role motivation plays in the teaching and learning process.

Motivation, to a great extent, energizes human behavior and "gives it direction” (Dörnyei, 1998, p. 117). In language learning, motivation exerts a significant impact (Gardner, 1985; Gardner, Masgoret, Tennant, \& Mihic, 2004; Guthrie \& Wigfield, 2000; Lightbown \& Spada, 1993). A large continuum of theories covers the many variables that affect student motivation in the second language (L2) classroom.

Not much has been written on L2 motivation, and whatever exists is drawn from the research by Clement (1980), Gardner (1983, 1985), Gardner and Lambert (1972), and a few others researching in the same area. The pioneer researchers who studied the relationship of learner's attitudes and motivation for second language learners were Gardner and Lambert (1972). They presented a differentiation between integrative and instrumental motivation for foreign language learners.

Some of these studies have investigated the EFL/ESL students' motivational constructs when learning English as foreign/second language. A meta-analysis study conducted by Masgoret and Gardner (2003) attempted to investigate the role of attitudes and motivation in second language learning. The major purpose of their study was to examine the relationship between the second language achievement and the five attitude/motivation variables in relation to the socioeducational model (integrations, motivation, and attitudes toward the learning situation, motivation, integrative orientation, and instrumental orientation). They derived the meta-analysis of their study to investigate what best estimated the aspects of second language achievement. They discussed the five attitudinal and motivational characteristics as listed in an earlier Masgoret/Gardner's model. They intended to discern if there were other variables, such as the availability of the language in the community that influenced the magnitude of these associations. The meta-analysis examined 75 independent samples involving total of 10,489 individuals. The study established the correlations between achievement and motivation. Motivation was found to be the strongest among the factors tested.

With regards to the effects of the sociocultural setting, Masgoret and Gardner (2003) confirmed in their findings the significant correlation between motivation and second language achievement. They, however, found that the impact of motivation on language acquisition may vary depending on whether the students were learning a second or a foreign language, which is in turn dependent on the availability of the language in the community and other sociopolitical presence (inputs) of the language in the community (Masgoret \& Gardner, 2003, p. 178). Their main finding was that motivation played a key role in the success in second language acquisition.

Wigfield and Eccles (2000) defined motivation by discussing the nature of expectancy and value constructs of motivation. In their study they sketched the expectancy value theory to confirm the expectancies and values “....assumed to be influenced by task specific beliefs such as ability beliefs, the perceived difficulty of different tasks, and individuals' goals, self-schema, and affective memories” (Wigfield \& Eccles, 2000, p. 69). Their main finding, according to the confirmatory factor analysis (CFA) was that no disparity was found between learners' ability beliefs and expectancies for success.

Furthermore, a brief research report was found conducted by Cox and Guthrie (2001) investigating the motivational and cognitive contribution with regards to students' amount of reading. A total of 251 students participated in this experiment. The finding of their study confirmed that the amount of reading is determined by cognitive and motivational constructs. In this study intrinsic motivation was listed as curiosity, involvement, 
readiness for challenge, and importance; while extrinsic motivation referred to motivational goals of recognition and competition.

Takase (2007) investigated the factors that motivate Japanese high school students to read English extensively. In his study 219 students were assessed after participating in an extensive reading program for one academic year. Takase (2007) tried to make a distinction by investigating the similarities and differences between L1 (first language) and L2 (second language) reading motivation. The two strongest components that emerged from this study were intrinsic motivation for L2 and intrinsic motivation for L1 reading motivation. The main finding of this study that intrinsic motivation is the most influential factor in L2 \& L1 reading motivation. However, he reported no positive relationship between L1 reading motivation and L2 reading motivation.

Moreover, another research study performed by Csizér and Dörnyei (2005) defined and described second language (L2) learner's motivational profiles. A total of 4,765 students participated in this study. The participants had to complete a survey questionnaire which was specifically designed for the purpose of the study to assess the various students' attitudes towards learning five target languages (English, German, French, Italian, and Russian), attitudes toward the L2 community, and self-confidence in L2 learning. The result of their study indicated that there are four "broad" motivational profiles for L2 learners, the two main are: least motivated learners, who are not interested in foreign languages, cultures, and language learning, and the most motivated learners who showed strong interest in learning foreign languages and culture. However, their study confirmed that on both groups motivation was the predictor to measure achievement in L2.

Ruddell and Unrau (1997/2004) examined the teacher's role in student's motivation and responsive teaching. Their study was supported by Huang (2010) who discussed motivation by examining students' reactions to different types of class assessments and by using motivating learning strategies. Eccles and Wigfield (2002) explained how the theories of motivational, beliefs, values, and goals work together for the best learning outcome with a passing emphasis on cultural background.

While motivation has been examined and defined in many ways, in this paper it is simply used by the researcher to find if there is any correlation between students motivation and students achievement. Many approaches are used by researchers to measure student's motivation; the most common one is the Motivation for Reading Questionnaire (MRQ) by Wigfield.

\section{Setting and Sample}

For this correlational study, a sample of 60 college-level students studying EFL at the intermediate or advanced level was randomly selected. The participants, of whom 30 (50\%) were male and 30 (50\%) were female, ranged in age from 17 to 25 years. They came from various parts of Sudan, primarily from small villages, and were all either sophomore or senior students in the Faculty of English Language and Translation at the time of the study.

\section{Instruments}

Motivation for learning English as a foreign language survey (MLEFL). Motivation for Learning English as a Foreign Language (MLEFL) is a six-question survey on which respondents selected one of four choices: Strongly Disagree, Disagree, Agree, and Strongly Agree (see Appendix A). The survey was developed to meet the goals of the study by focusing on college-level students' motivation in learning EFL. The items in the 
survey, which assess various motivational mechanisms identified in previous research, were derived from an extensive review of existing resources and of the literature on EFL and ESL learning motivation (Wigfield \& Guthrie, 1997). To assure content validity the survey was distributed to thirty six EFL educators in twelve different countries around the world; those countries are: Algeria, Bahrain, Egypt, Jordan, Kuwait, Morocco, Qatar, Saudi Arabia, Sultanate Oman, Sudan, Thailand, and the United Arab Emirates. The responses received indicated that the survey thoroughly measured students' motivation to learn EFL. In addition, testing for reliability yielded at Cronbach's Alpha of 0.75 , which is considered a very good score. Moreover, each question in the survey has presumed relevance to the property being measured, and internal consistency reliability is well established.

The Test of English as a Foreign Language (TOEFL). The Test of English as a Foreign Language (TOEFL) is a norm-referenced test designed to compare individual performance with the performances of all the other students in a norm group, across a continuum of general language abilities. As such, it is often used as a stand-in measure for English language proficiency. In terms of reliability and validity, the TOEFL test is the most widely respected English-language test in the world. First administered in 1964 and since taken by nearly 20 million students, TOEFL is recognized by more than 9,000 colleges, universities and agencies in more than 130 countries, including Australia, Canada, the UK, and the United States (ETS.org). TOEFL is a registered trademark of Educational Testing Service (ETS).

\section{Data Collection}

Participants completed the MLEFL on their school campus. Research assistants administered the surveys, explained the instructions and the meaning of the survey items in the students' first language, in the researcher's presence. Participants took the TOEFL test the following day, also on campus. They were given 25 minutes to complete each section of the TOEFL test.

\section{Data Analysis}

For the survey results, a Pearson Correlation was employed to examine between subject factors, the relationship between students' motivation and achievement. Following is the Pearson Correlation.

\section{Results}

\section{Research Question 1}

According to the MLEFL survey, what are the motivational factors for sophomore and seniors, males and females Sudanese college students to learn English as a foreign language?

This question was answered based on the students' responses to the six MLEFL categorical questions. The responses to each of the six questions were analyzed using the Chi-Square procedure. The first set of analysis looked at differences between males $(\mathrm{N}=30)$, and females $(\mathrm{N}=30)$ for each of the six questions. While there was no significant difference between males and females, the response within each group to each question's categories (Strongly Disagree, Disagree, Agree, and Strongly Agree) was significantly different. The responses to the "Strongly Agree" category was significantly different from the other categories.

On the MLEFL the questions were posed at statements and are elucidated below:

Question 1: "English language is very important to me”; this question was aimed at gauging student ratings 
about the importance of learning English. The findings indicated that the females responses were significant in the "Strongly Agree" $\left(\chi^{2}=48.6, p=.000\right)$. A similar pattern was found for the male students $\left(\chi^{2}=38.6, p=.000\right)$.

Question 2: "I make extra efforts to learn English well”; this question directly addressed student's motivation and the efforts they make to learn English. The females responses were significant to the "Strongly Agree" category $\left(\chi^{2}=16.6, p=.001\right)$. A similar pattern was found for the male students $\left(\chi^{2}=14.0, p=.003\right)$.

Question 3: "I enjoy learning English even though it is sometimes hard"; the females' responses were significant to the "strongly agree" category $\left(\chi^{2}=18.80, p=.000\right)$. A similar pattern was found for the male students $\left(\chi^{2}=13.46, p=.004\right)$.

Question 4: "I want to learn English because it is fun”; the females' responses were significant to the "Strongly Agree" category $\left(\chi^{2}=10.80, p=.013\right)$. A similar pattern was found for the male students $\left(\chi^{2}=10.40\right.$, $p=.018)$.

Question 5: "I want to learn English because I can get a good paying job when I graduate”; the females responses were significant to the "Strongly Agree" category $\left(\chi^{2}=28.40, p=.000\right)$. A similar pattern was found for the male students $\left(\chi^{2}=15.06, p=.002\right)$.

Question 6: "I want to learn English to communicate with my online friends all over the world"; the females responses were significant to the "Strongly Agree" category $\left(\chi^{2}=10.00, p=.019\right)$. A similar pattern was found for the male students $\left(\chi^{2}=10.26, p=.016\right)$.

For the second set of analyses, the responses to the same questions were analyzed based on students' grade level sophomore and seniors on each of the six questions. While there were no significant difference between sophomores and seniors, the response within each group to each question was significantly different. The result illustrated on table 1 (see Appendix B).

\section{Research Question 2}

Is there a significant difference between TOEFL scores of males and females, sophomores and seniors Sudanese college level students?

The passing score for the TOEFL test is $12 / 20$. Results indicated that $89 \%$ of the students scored at or above the passing score in a sample TOEFL test used on this study. Ninety percent of the students scored the highest in the reading comprehension part of the test. The challenging area was the vocabulary part; as many of the students with the highest overall score on the test scored the lowest on the vocabulary part. The overall test's passing scores of males and females reported to be the same; as well as the passing percentage between sophomore and senior students. However, sophomore students scored higher on the written expression part of the test than senior students. On the sentence structure part of the test, senior students scored the highest. Males and females reported to be at the same level.

Students' academic achievement as measured by the TOEFL was analyzed by means of a two way between subjects ANOVA with two levels of gender (male and female) and two levels of grade level (sophomore and seniors). There were no significant main effects for gender, $F(1,56)=.712, p=.402$ or grade level $F(1,56)$ $=.870, p=.355$. There was no significant interaction between gender and grade level, $F(1,56)=.018, p=.894$. Result illustrated on Table2 (see Appendix C). 


\section{Research Question 3}

What is the relationship between motivation and achievement for college level Sudanese students?

Students' motivation (MLEFL) was used in a multiple regression analysis to predict the students' achievement as measured by the TOEFL scores. There was a significant correlation between the two variables.

The prediction model was statistically significant, $F(2,57)=15.509, p<.001$ and accounted for approximately $35 \%$ of the variance $\left(R^{2}=.352\right.$, Adjusted $R^{2}=.330$. The MLEFL was a significant predictor of the TOEFL predicting $6 \%$ of the unique variance of TOEFL. The results indicated that motivation is a significant predictor of achievement. The result illustrated on Table 3 (see Appendix D).

\section{Discussion and Conclusion}

The main theme in this study was to continue the ongoing debate over the relationship among student's motivation and student's achievement when learning English as a foreign language. It is a perpetual issue which has been overwhelming the field of academia, particularly since the emergence of educational-psychological research. In the EFL/ESL area this dilemma is doubled due to the lack of research in this area. Therefore, this study examined whether student's achievement in learning English as a foreign language might be predicted from student's motivation.

This study established a statistically significant relationship between student's achievement and student's motivation measured by MLEFL when learning English as a foreign language. Students' motivation was found to be a strong predictor of their achievements when learning English as a foreign language. This finding supports the results of several experimental research studies that indicated there is a positive correlation between students' motivation and school achievement (Guthrie \& Wigfield, 2000; Guthrie, et al., 2007; Linnenbrink \& Pintrich, 2003).

This finding contributes to the study by illustrating the usefulness of the of the MLEFL survey. This instrument "MLEFL" was specifically designed for this study to measure student's “motivation” to learn English as a foreign language. Hence this study provided evidence of validity of MLEFL to measure student's motivation to learn English as a foreign language.

The significant correlation between student's motivation and achievement was the indicator of the validity of the score obtained from this survey. The reliability of scores from the subscales of this measure was very good as indicated by Coronbach Alpha's at 0.75 ; which was also related to the significant finding related to these subscales.

Additionally, this study investigated the gender characteristic, an area that has not been examined meticulously in the EFL world in general, and particularly in Sudan. The results of the ANOVA indicated that there is no difference between males and females either in motivation. Therefore it is worth mentioning that gender makes no difference in this study. This particular finding contradicted the findings of several studies in the field of foreign language learning motivation which reported that female students were more motivated to studying a foreign language than male students (Gardner \& Lambert, 1972).

\section{Recommendations and Limitations}

Even though, the present study used correlation and regression analysis which are perfectly well-matched 
for explaining the fundamental relationships between motivation and achievement, it is still difficult to determine whether Sudanese college students' performance on the TOEFL test alone can determine this relationship.

Additionally, this study only investigated the motivation and achievement of Sudanese college level students. The results, therefore; should not be considered to generalize to any other cultural groups or grade level. Therefore, it is recommended to include other cultural groups from different grade levels to participate. Also for future research the use of qualitative and quantitative research in similar studies should put more focus on looking further at the multifaceted relationship between students’ motivation to learn English as a foreign language and their achievement.

\section{Conclusion}

The purpose of this research was to investigate what motivates people to learn a foreign language and why they stay motivated. Students' motivation was examined through a survey, a norm-referenced scale, and a test to measure their achievement. I had strong belief in the urgency of investigating motivational constructs, examining the gender differences in student's motivation. Yet, in the future, a plan is in consideration to initiate studies on establishing a database of some of the best teaching techniques to facilitate English language learning, particularly for English language learners of other languages.

\section{References}

Alexander, A. (1997). Knowledge seeking and self-schema: A case for the motivational dimension of exposition. Educational Psychologist, 32(2), 83-94.

Alharthy, I., \& Was, C. (2010). Goals, efficacy and metacognitive self-regulation. International Journal of Education, 2, 1-20.

Bandura, A. (1997). Self-efficacy: The exercise of control. New York: Freeman.

Bandura, A., \& Locke, E. (2003). Negative self-efficacy and goal effects revisited. Journal of Applied Psychology, 88(1), 87-99.

Clement, R. (1980). Ethnicity, contact and communicative competence in a second language. In H. Giles, W. P. Robinson, and P. M. Smith (Eds.), Language: Social psychological perspectives (pp. 147-154). New York, NY: Pergamon.

Cox, K. E., \& Guthrie, J. T. (2001). Motivational and cognitive contributions to students' amount of reading. Contemporary Educational Psychology, 26(1), 116-131.

Dörnyei, Z. N. (1998). Motivation in second and foreign language learning. Language teaching (Series Ed.), Cambridge Journal Research Series, 31. Teaching surveys and studies (pp. 117-135). doi:10.1017/S026144480001315X

Dörnyei, Z. (2010). Researching motivation: From integrativeness to the ideal L2 self. In S. Hunston and D. Oakey (Eds.), Introducing applied linguistics: Concepts and skills (pp. 74-83). London: Routledge.

Eccles, J., \& Wigfield, A. (2002). Motivational beliefs, values, and goals. Annual Review of Psychology, 53, $109-141$.

Gardner, H. (1983). Frames of mind: The theory of multiple intelligences. New York: Basic Books.

Gardner, R. C. (1985). Social psychology and second language learning. London: Edward Arnold.

Gardner, R. C., \& Lambert, W. E. (1972). Attitudes and motivation in second language learning. Rowley, MA: Newbury.

Gardner, R. C., Masgoret, A. M., Tennant, J., \& Mihic, L. (2004). Integrative motivation: Changes during a year-long intermediate level language course. Language Learning, 54(1), 1-34. doi:10.1111/j.1467-9922.2004.00247.x. Retrieved from http://dx.doi.org/ 10.1111/j.1467-9922.2004.00247.x

Guthrie, J., \& Wigfield, A. (2000). Engagement and motivation in reading. In M. L. Kamil, P. Mosenthal, P. D. Pearson, and R. Bar (Eds.), Handbook of reading Research (pp. 609-640), NJ: Lawrence Erlbaum.

Guthrie, J. T., Hoa, L. W., Wigfield, A., Tonks, S. M., Humenick, N. M., \& Littles, E. (2007). Reading motivation and reading comprehension growth in the later elementary years. Contemporary Educational Psychology, 32, 282-313.

Huang, S. (2010). Convergent vs. divergent assessment: Impact on college EFL students' motivation and self-regulated learning strategies. Language Testing Journal, 28(2), 251-271. doi:10.1177/0265532210392199

Lightbown, P., \& Spada, N. (1993). How languages are learned. Oxford University Press: Issues in Applied Linguistics, $6(1), 135$.

Lincoln, F., \& Rademacher, B. (2006). Learning styles of ESL students in community colleges. Community College Journal of 
Research and Practice, 30, 485-500.

Linnenbrink, E. A., \& Pintrich, P. R. (2003). The role of self-efficacy beliefs in student engagement and learning in the classroom. Reading \& Writing Quarterly: Overcoming Learning Difficulties, 19, 119-137.

Masgoret, A., \& Gardner, R. C. (2003). Attitudes, motivation, and second language learning: A meta-analysis of studies conducted by Gardner and associates. Language Learning, 53(1), 123-163.

Ruddel, R. B., \& Unrau, N. J. (1997/2004). The role of responsive teaching in focusing reader intention and developing reader motivation. In R. Ruddel and N. Unrau (Eds.), Theoretical models and processes of reading (pp. 979-995). Newark, DE: International Reading Association.

Takase, A. (2007). Japanese high school students' motivation for extensive L2 reading. Reading in a Foreign Language, 19(1), $1-18$.

Wigfield, A., \& Eccles, J. (2000). Expectancy-value theory of achievement motivation. Contemporary Educational Psychology, 25, 68-81. doi: 10.1006/ceps.1999.1015

Wigfield, A., \& Guthrie, J. T. (1997). Relations of children's motivation for reading tothe amount and breadth of their reading. Journal of Educational Psychology, 89, 420-432. 
Modified Motivation for Reading Questionnaire

Motivation for Learning English as a Foreign Language (MLEFL)

Student Name (Optional):

Gender (Must check one): M $\mathbf{F}$

Please think about your experience learning English language. Mark the answer that best represents how you feel and think of yourself as student learning English in the each of the statements below.

Place a Check next to your most preferred answer for each question.

Learning English is very important to me.

1/Strongly Disagree 2/Disagree 3/Agree 4/Strongly Agree

I do extra efforts to learn English well

1/Strongly Disagree 2/Disagree 3/Agree 4/Strongly Agree

I enjoy learning English even though it is sometimes hard.

1/Strongly Disagree 2/Disagree 3/Agree 4/Strongly Agree

I want to learn English because it is fun

1/Strongly Disagree 2/Disagree 3/Agree 4/Strongly Agree

I want to learn English because I can get a good paying job when I graduate

1/Strongly Disagree 2/Disagree 3/Agree 4/Strongly Agree

I want to learn English to communicate with my online friends all over the world 4/Strongly Agree 
Table 1

Analysis of the Questions of MLEFL Analyzed by Grade Level

\begin{tabular}{|c|c|c|c|c|}
\hline \multirow{2}{*}{ Questions } & \multicolumn{2}{|c|}{ Sophomores } & \multicolumn{2}{|c|}{$\underline{\underline{\text { Seniors }}}$} \\
\hline & Chi-Square & Sig & Chi-Square & Sig \\
\hline Q1: English language is very important to me & 48.66 & .000 & 38.60 & .000 \\
\hline Q2: I do extra efforts to learn English well & 12.13 & .007 & 19.86 & .000 \\
\hline Q3: I enjoy learning English even though it is sometimes hard & 16.66 & .001 & 14.00 & .003 \\
\hline Q4: I want to learn English because it is fun & 26.20 & .000 & 6.80 & .079 \\
\hline $\begin{array}{l}\text { Q5: I want to learn English because I can get a good paying job } \\
\text { when I graduate }\end{array}$ & 11.67 & .011 & 34.26 & .000 \\
\hline $\begin{array}{l}\text { Q6: I want to learn English to communicate with my online } \\
\text { friends all over the world }\end{array}$ & 7.06 & .070 & 13.46 & .004 \\
\hline
\end{tabular}

\section{Appendix C}

Table 2

Tests of Between Subjects Effects for Dependent Variable: Student's TOEFL Score

\begin{tabular}{llllllc}
\hline Source & Type III Sum of Squares & $d f$ & Mean Square & $F$ & Sig. & Partial Eta Squared \\
\hline Student Gender & 6.017 & 1 & 6.017 & .712 & .402 & .013 \\
Student Grade Level & 7.350 & 1 & 7.350 & .870 & .355 & .015 \\
Student Gender * & .150 & 1 & .150 & .018 & .894 & .000 \\
Student Grade Level & & & & & \\
Error & 473.067 & 56 & 8.448 & & & \\
Total & 12107.000 & 60 & & & & \\
Corrected Total & 486.583 & 59 & & & &
\end{tabular}

a. $R^{2}=.028$ (Adjusted $R^{2}=-.024$ ).

No significant gender, grade level differences, no interaction.

\section{Appendix D}

Table 3

Achievement - MLEFL

\begin{tabular}{lllll}
\hline Variable & $M$ & $S D$ & $1-\mathrm{MLEFL}$ & $2-\mathrm{GSE}$ \\
TOEFL & 13.92 & 2.872 & $.572^{* *}$ & $.539^{*}$ \\
\hline Prediction Variables & & & & .762 \\
1-MLEFL & 19.83 & 3.75 & & .752 \\
\hline
\end{tabular}

${ }^{*} \mathrm{p}<.001$. 